\title{
Extreme morphological plasticity enables a free mode of life in Favia gravida at Ascension Island (South Atlantic)
}

\author{
B. W. Hoeksema
}

Received: 5 July 2011 / Revised: 3 October 2011 / Accepted: 30 November 2011 /Published online: 11 January 2012

(C) The Author(s) 2012. This article is published with open access at Springerlink.com

\begin{abstract}
Samples of free-living corals of Favia gravida (Scleractinia: Faviidae) have been studied. They were collected from an intertidal rock pool on Ascension Island, southern Atlantic Ocean. They consist of phaceloid clusters of corallites that appear to be able to easily break apart from each other by the formation of slits inbetween them, which indicates the occurrence of asexual reproduction by fragmentation. The base of the fragments is usually tapering or conical and covered by an epitheca. Small corallites on the base of some specimens suggest that the corals also reproduce by budding. By not depending on a solid substratum for reproduction, the corals appear to be utterly adapted to a free mode of life. These traits have not been reported before from Favia, which normally consists of massive corals. The variable shape of the corals at hand indicate that they have adopted a plastic free-living growth form that appears to be confined to a rock pool habitat.
\end{abstract}

Keywords Asexual reproduction · Budding - Epitheca . Fragmentation $\cdot$ Free-living $\cdot$ Isolation $\cdot$ Rock pool

\section{Introduction}

The scleractinian coral family Faviidae has a long tradition regarding studies dealing with intra-specific ecophenotypic variation. These studies deal mostly with the dimensions and spacing of corallites, which appear to respond to light

B. W. Hoeksema $(\bowtie)$

Department of Marine Zoology,

Netherlands Centre for Biodiversity Naturalis,

P.O. Box 9517, 2300 RA Leiden, The Netherlands

e-mail: bert.hoeksema@ncbnaturalis.nl and sedimentation (Laborel 1969; Wijsman-Best 1974; Foster 1979, 1980; Budd 1993; Van Veghel and Bak 1993; Amaral 1994; Todd et al. 2001, 2004; Amaral and Ramos 2007; Ow and Todd 2010; Chen et al. 2011). This habitatinduced phenotypic variability has often hampered the recognition of species and also of monophyletic groups at higher taxonomic levels within the Faviidae (Fukami et al. 2004; Huang et al. 2009; Budd and Stolarski 2011). Since most Faviidae species are attached and massive, they have so far not been known to reproduce asexually by fragmentation or by budding, which are life history traits shown by corals with a free mode of life, such as free-living species in various Fungiidae clades (Hoeksema 1989, 1991, 2004; Hoeksema and Gittenberger 2010; Hoeksema and Yeemin 2011; Gittenberger et al 2011; Hoeksema and Waheed 2011) and in the Flabeliidae (Cairns 1989).

Therefore, it was a surprise that during a recent study of Atlantic Favia specimens in the coral collection of NCB Naturalis in Leiden, two lots of small unattached corals were discovered that belong to Favia gravida (Verrill, 1868). According to their label, they were collected from an intertidal rock pool on Ascension, an isolated island in the South Atlantic Ocean (Fig. 1). Two anonymous reviewers brought additional material from the same locality to my attention, which was consequently also studied. The material is described, illustrated and discussed here in the light of an extreme morphological variety within Favia, enabling it to reproduce asexually and to colonize various substrates as a free-living coral.

\section{Material}

The specimens were part of coral collections in natural history museums (abbreviations below). 


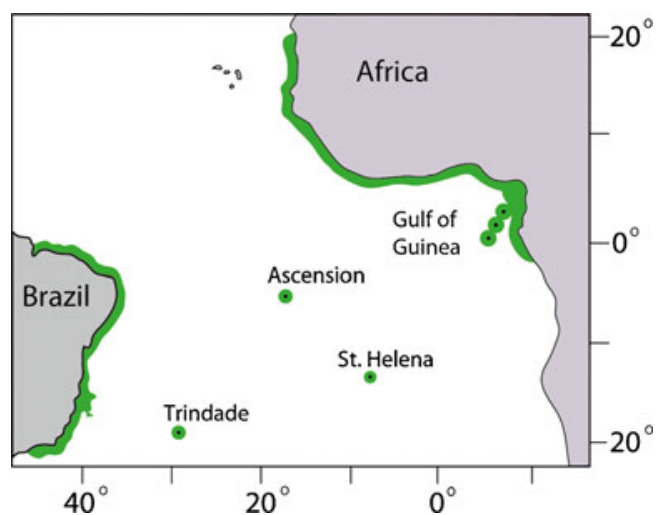

Fig. 1 Distribution range of Favia gravida (after Laborel 1974; Gasparini and Floeter 2001; Amaral and Ramos 2007; modified from Aronson et al. 2008 for F. fragum)

Type specimens of Favia gravida: two syntypes (YPM 1465a, 1465b) from Brazil, Bahia State, Abrolhos Archipelago, Abrolhos Reef, coll. CF Hartt, 1867 (see also Verrill 1901, Pl. 13, Fig. 3); one syntype (YPM 4549) from Brazil, Pernambuco State, Recife, coll. CF Hartt, 1867.

Free-living specimens of $F$. gravida: RMNH Coel. 17339 (16 specimens) from "Ascension Island, SW Coast, Shelley Beach, Coral Pool", 1 June 1983, coll. JC den Hartog; RMNH Coel. 23341 (two specimens) from "Ascention, Shelly Beach", 10 November 1989, coll. JH Stock. USNM 78222 (one specimen) from "South Atlantic Ocean, Ascension Island, South Shelly Beach", 20 November 1985, coll. JT; USNM 78223 (one specimen) from "South Atlantic Ocean, Ascension Island, South Shelly Beach", 1 December 1985, coll. JT; USNM 89298 ( $\approx 80$ specimens and fragments) from "Ascension Island (South Atlantic), inland tidepool at Shelly Beach, 200-300 ft from intertidal areas bottom paved with coral", 23 May 1971, coll. RB Manning; USNM 96980 (five specimens and fragments) from "Ascension Island (South Atlantic), tidepool at Turtle Shell beach", 25 May 1971, coll. RB Manning; USNM 96981 (one specimen from "Ascension Island (South Atlantic), North East Bay, beach and tidepools on rocky point, West of main beach", 19 May 1971, coll. RB Manning; USNM 96983 ( $\approx 40$ specimens and fragments) from "Ascension Island, Shelly Beach, Procaris pool”, 13 July 1976, coll. Jones, Manning, Pawson, Provenzano, Rosswater.

Attached specimens of $F$. gravida: RMNH Coel. 17341 (8 specimens) from "Ascension Islands, Mars Bay, SW coast, exposed rocky shore with tidal pools", 31 May 1983, coll. JC den Hartog; USNM 96368 (four specimens and fragments) from "Ascension Island (South Atlantic), Shelly Beach tidepools in flat exposed at low tide on open beach", 23 May 1971, coll. RB Manning; USNM 96984 (one specimen) from "Ascension Island, MacArthur Point. Associated with rocks in intertidal", 13 July 1976, coll. Jones, Manning, Pawson, Provenzano, Rosswater.
RMNH $=$ Netherlands Centre for Biodiversity Naturalis, Leiden, The Netherlands (formerly known as Rijksmuseum van Natuurlijke Historie). YPM = Peabody Museum of Natural History, Yale University, New Haven, Connecticut, U.S.A. USNM = Smithsonian Institution, National Museum of Natural History, Washington DC, U.S.A. (formerly known as U.S. National Museum of Natural History).

\section{Locality and habitat}

Ascension is an isolated volcanic island in the South Atlantic (Fig. 1). It lies about 2,200 km east of Brazil and more than $3,000 \mathrm{~km}$ west of the African coast. The nearest island is St. Helena, almost $1,300 \mathrm{~km}$ to the southeast.

In the first record of Favia from Ascension, the corals were referred to as "irregular beds of coral (Favia)" in rock pools, one of which was called "coral pool", on Shelley Beach near the southernmost point of the island (Chace and Manning 1972). In another publication, these authors referred to "solitary corals" and "beds of the solitary coral Favia" (Manning and Chace 1990). The corals were observed to host barnacles of the species Troglocarcinus corallicola Verrill, 1908, in rock pools, and were also at a depth of $3 \mathrm{~m}$ inside a bay. In a more detailed study, Price and John (1980) refer to rock pools that are lined "with coral growths (Favia sp.)" and a bottom consisting of loose marl-like sediment and sand. They present an illustration (Price and John 1980: Fig. 12) showing dense patches of coral. Abele and Felgenhauer (1985) mention that the largest coral pool is approximately $7 \mathrm{~m}$ long, $5 \mathrm{~m}$ wide, and $1 \mathrm{~m}$ deep.

However, F. gravida from Ascension also appears to be mentioned in much older literature, in which it was referred to as Platygyra ascensionis Ridley 1881, which apparently is a junior synonym of $F$. gravida (see Ridley 1881 ; Werner 1996). There are no records of other zooxanthellate corals from Ascension, except those mentioned in an unpublished MS thesis (Werner 1996) concerning Madracis decactis (Lyman 1859) and Siderastrea radians (Pallas, 1766).

\section{Results}

The free-living specimens of $F$. gravida from intertidal pools at Shelley Beach, Turtle Shell Beach, and North East Bay (RMNH Coel. 17339, 23341; USNM 78222, 78223, 89298, 96980, 96981, 96983) form a mix of loose corals and coral fragments. The largest specimens ( $\varnothing$ up to $13 \mathrm{~cm}$ ) resemble phaceloid bundles of corallites, some of which show indications of potential fragmentation (Fig. 2). There are no marks of previous attachment to a substratum. Small 
Fig. 2 Detached corals of $F$. fragum from Ascension I. Scale bars $1 \mathrm{~cm}$. Largest specimen $(\varnothing 7.6 \mathrm{~cm})$ viewed from above (a) and from aside $(\mathbf{b}, \mathbf{c})$ consisting of phaceloid clusters of corallites, which are connected at the base and show an epithecal crust. Two clusters are almost broken off at the base (arrows). d Smaller specimen $(\varnothing 4.7 \mathrm{~cm})$ showing two clusters of corallites, one of which is almost detached (arrow)
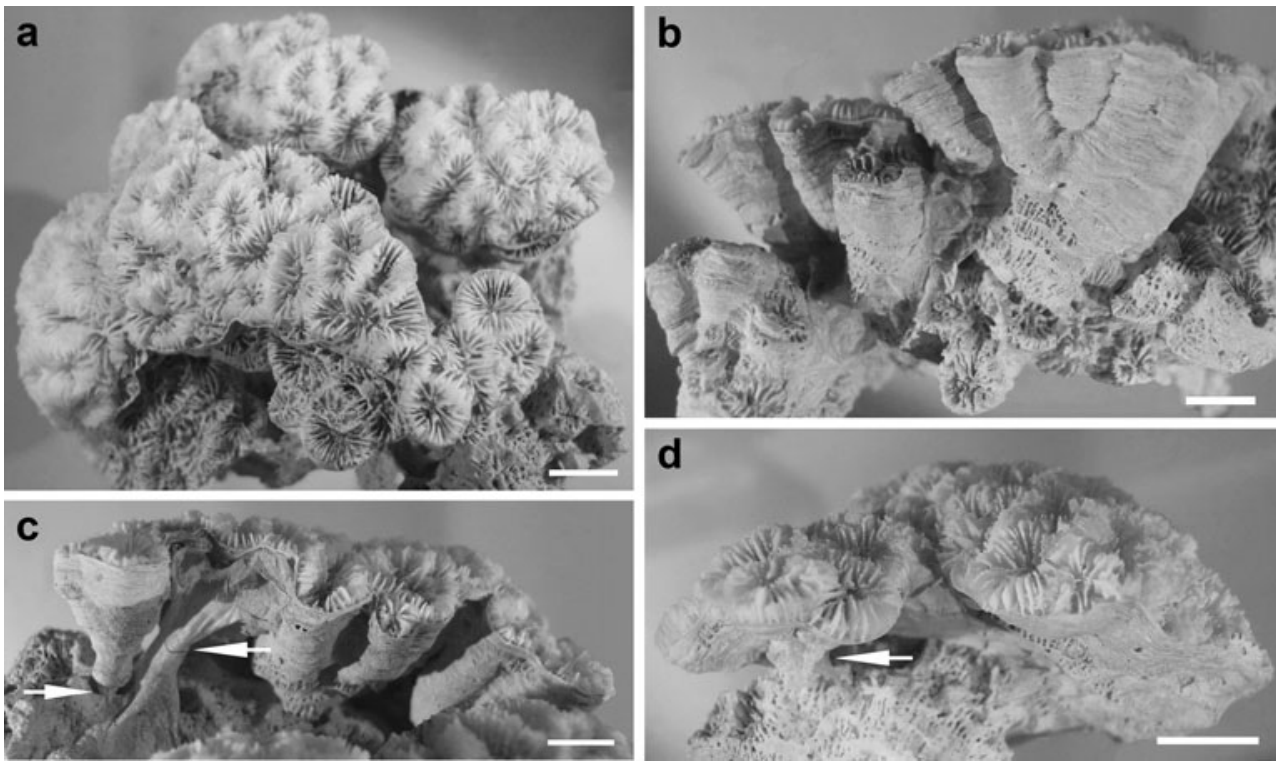

specimens have a distinct free-living shape, showing a tapering or conical base covered by an epitheca (Fig. 3). The smallest corals consist of a single corallite $(\varnothing \approx 0.5 \mathrm{~cm})$. Some specimens of medium size consist of two or three cones of corallites, like Siamese twins or triplets, which look as if they may easily break apart (Fig. 4). Several specimens show a large detachment scar, where they may have become separated from a clone sibling (Figs. 3, 4 and 5). Such scars are not covered by an epithecal crust. Some specimens show small polyps at their underside $(\varnothing 0.1-2.2 \mathrm{~mm})$, which may be asexually produced buds or recruits settled after local planulation (Fig. 5). F. gravida corals from other Ascension Island localities (RMNH Coel. 17341, USNM 96368, 96984) are massive and do not show signs of fragmentation. Parts of the undersides that have not been in contact with the substratum are covered by an epithecal crust.

\section{Discussion}

The zooxanthellate scleractinian coral Favia gravida has an amphi-Atlantic distribution from Brazil to western Africa, including the mid-oceanic islands Ascension and St. Helena, which are ca. 1,300 km apart (Fig. 1). In Brazil, the species occupies a large array of shallow-water habitats and shows much morphological variability by forming solid and dense attached colonies, which are encrusting or hemispherical with a strongly developed epitheca at their sides (Amaral and Ramos 2007). F. gravida resembles F. fragum (Esper, 1793), another species with an amphi-Atlantic range (Hoeksema et al. in press). Molecular evidence supports their status as two genetically distant species (Nunes et al. 2008, 2011). The type specimens of $F$. gravida are massive corals. Their calices and those of the specimens from Ascension I. fit
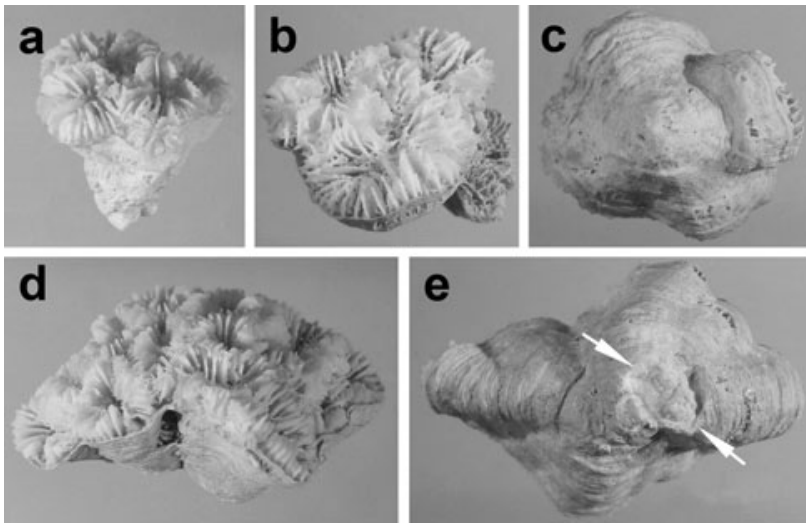

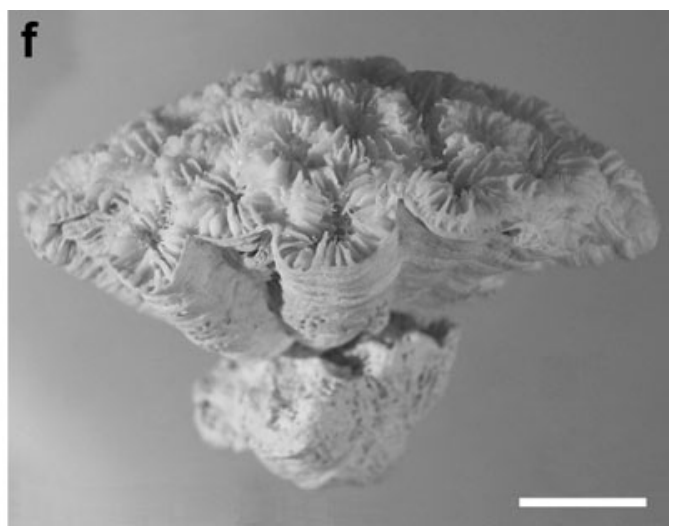

dead corallite. d, e Specimen showing a scar possibly indicating area with which it was attachment to a clone sibling (arrows). f Large coral still attached to dead fragment
Fig. 3 Free-living corals of $F$. fragum from Ascension I. ( $\varnothing 1.4$ $4.5 \mathrm{~cm})$. The base is tapering towards a point and covered by an epitheca. Scale bar $1 \mathrm{~cm}$. a Smallest coral. b, c Small specimen with 

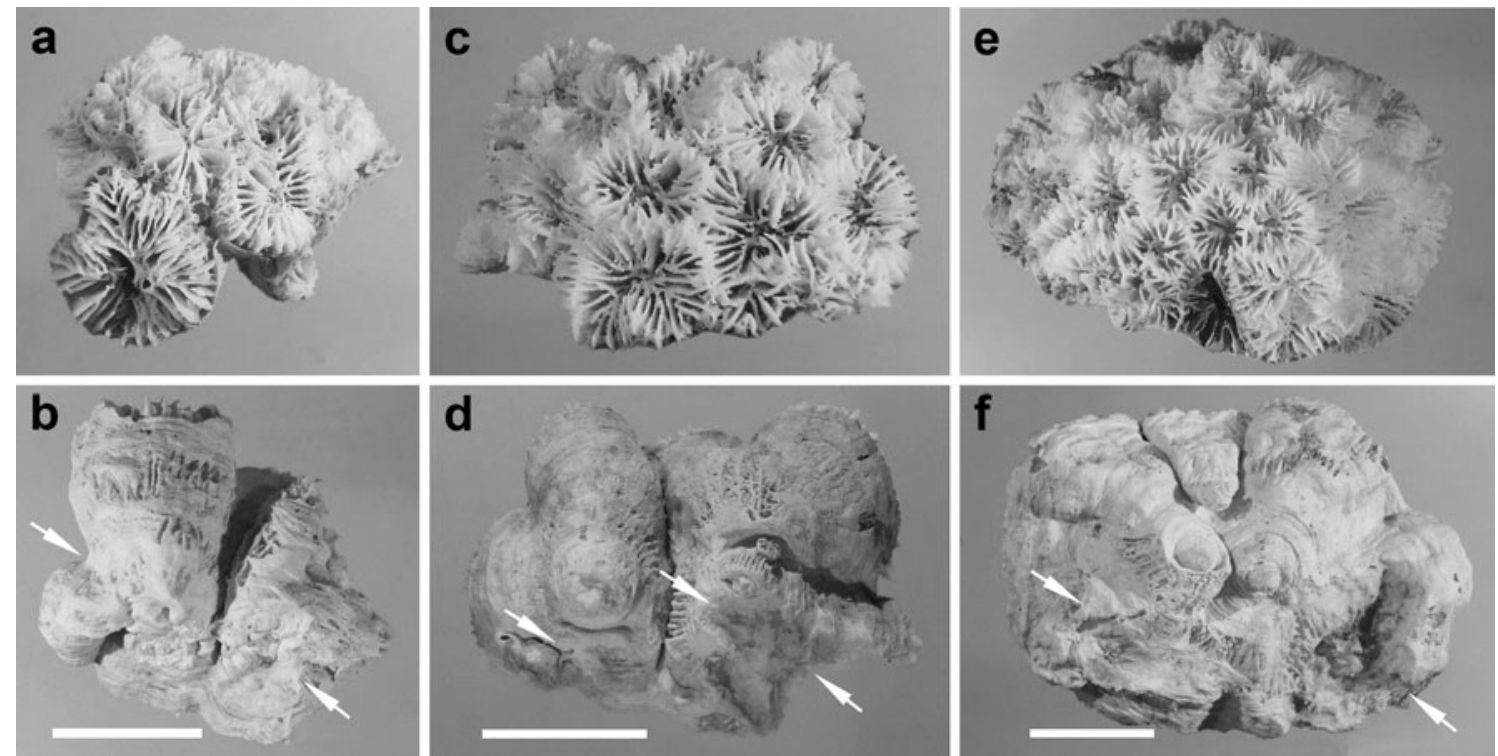

Fig. 4 Free-living corals of $F$. fragum from Ascension I. ( $\varnothing 2.4$ $3.4 \mathrm{~cm})$. They show slits at their underside, indicating potential fragmentation. All show a detachment scar at their underside (arrows).

within the morphological range of $F$. gravida described by Laborel (1969) and by Amaral and Ramos (2007).

Since Manning and Chace (1990) refer to the "solitary coral Favia", and the genus Favia only includes corals composed of multiple corallites, they may have confused "solitary" with "free-living", a term commonly associated with unattached solitary corals. Many studied samples of $F$. gravida corals from Ascension Island's Shelley Beach, all
Scale bar $1 \mathrm{~cm}$. a, b Smallest coral with clear fission zone. c, d Small specimen about to split in three parts. Small polyp may be a bud. e, f Large coral splitting at the base, with a small part almost loose

corals with a free-living growth form, were indeed collected from this "coral pool" (Figs. 3, 4 and 5). Most of these were sampled by Manning, although he did not mention collecting them (Manning and Chace 1990). This case confirms the importance of natural history collections in coral reef research (Hoeksema et al. 2011). Based on the description by Manning and Chace (1990), it would not be clear how their Favia corals really looked.
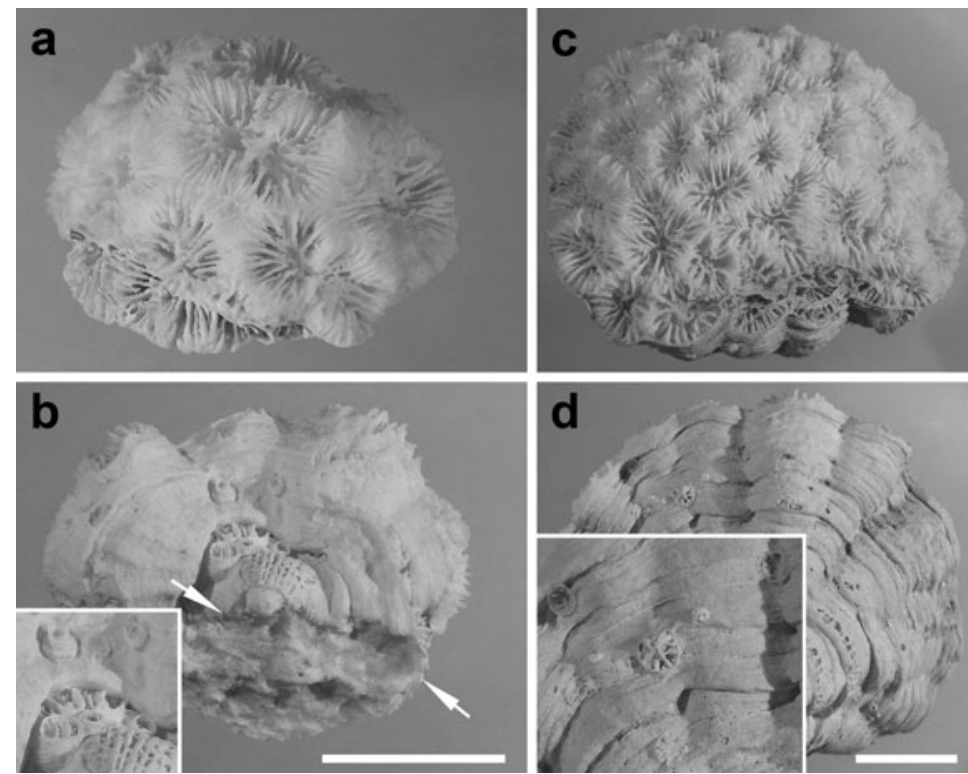
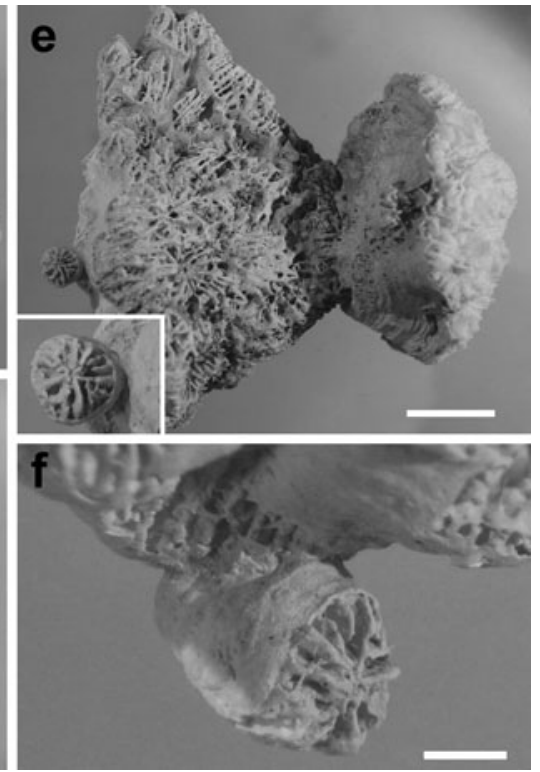

Fig. 5 Free-living corals of $F$. fragum from Ascension I. $(\varnothing 2.2-$ $4.1 \mathrm{~cm})$. They show small polyps, possibly indicating budding. Scale bar (a-e) $1 \mathrm{~cm}$. a, b Smallest coral showing detachment scar (arrows) and small polyps at underside (insert). c, d Large specimen showing small polyps (insert). e, f Dead fragment with attached bundle of corallites and a small polyp underneath (insert). f Close-up of small polyp, probably dead at the time of collecting. Scale bar $0.25 \mathrm{~cm}$ 
Hitherto, free-living corals have not been reported for Favia. The specimens of the present study lack any clear mark of attachment to a solid substrate and display a conical base partly or completely covered by an epitheca, indicating that they must have been free-living, like the faviid Manicina areolata (Linneaus 1758) (Barnes 1972; Hoeksema 1993; Roniewicz and Stolarski 1999). Moreover, some specimens are partly phaceloid and show signs of fragmentation, a trait associated with a free mode of life (Hoeksema 1993). The phaceloid clusters of corallites in the largest corals (Fig. 2) resemble stalked mushroom corals in their anthocaulus phase before detachment (Wells 1966; Hoeksema 1989; Hoeksema and Yeemin 2011).

Surviving fragments may colonize various kinds of substrates, including sand and marl. The epitheca may serve as a shield to protect the soft tissue when the coral is partly buried in the sediment. Apart from the barnacles mentioned by Manning and Chace (1990), which live on the upper side of the corals, there is no sign of epibiotic species as on the epitheca of Manicina corals (Harries and Sorauf 2010), a cleanliness indicating that they may have lived semi-buried in the substrate (Hoeksema 1993). It is also possible that the free-living corals are able to settle on the coarse marl sediment on the bottom of the rock pools from which they break apart without trace of attachment (Plusquellec et al. 1999).

The small corallites on the epitheca look like asexually produced buds, as shown by some mushroom corals (Scleractinia: Fungiidae) (Boschma 1922, 1923a, b; Hoeksema 1989, 2004), in Goniopora stokesi Milne Edwards \& Haime, 1851 (Scleractinia: Poritidae) (Boschma 1923c; Rosen and Taylor 1969; Hoeksema and Waheed in press), and some fossil taxa for which they have been called "hypocorallites" (Plusquellec et al. 1999). It is not clear how they could develop on the epitheca without contact with soft tissue. This is in contrast with budding by free-living mushroom corals, which are completely surrounded by soft polyp tissue. Extra-tentacular budding on the theca is also known from azooxanthellate corals. It is called "anthoblast production" or "bud shedding", in which the detached buds leave scars behind (Zibrowius 1985; Cairns 1988). In F. gravida, they may also be locally produced offspring coming from planula larvae that had settled on the parent corals, but, if the underside of the corals was buried in sediment, this is not likely unless the sediment was very coarse, like marl. In that case, the coral would be forming pseudo- or quasi-colonies as described for Balanophyllia generatrix Cairns and Zibrowius 1997 (Cairns and Zibrowius 1997: fig. $25 \mathrm{~g}-\mathrm{i}$ ).

The coral fragmentation of $F$. gravida resembles asexual reproduction by free-living mushroom corals, which helps them to disperse over the sea floor (Hoeksema 1989; Hoeksema and Gittenberger 2010; Hoeksema and Waheed 2011). This "sessile dispersal" may help corals to spread the risk of mortality in harsh environments (Jackson 1986).
The free-living growth form of $F$. gravida appears to be a result of ecophenotypic variation occurring in an unusual environment (rock pools) on Ascension Island. It has not been reported in studies dealing with $F$. gravida in Brazil (Verrill 1901a, b; Laborel 1969; Amaral and Ramos 2007). F. gravida specimens from Brazil and St. Helena I. deposited in museum collections (RMNH, YPM) or illustrated in publications (e.g., Correia 2011) also do not represent this ecomorph, even though some of these corals were mentioned to have occurred in tide pools (Verrill 1901b). A subspherical free-living growth form has recently been reported for the massive reef coral Madracis decactis (Scleractinia: Pocilloporidae). High densities of these corals were observed inbetween boulders on sand flats and rubble beds in subtropical water off southern Brazil (Capel et al. 2011 ), which indicates that a free-living $F$. gravida ecomorph is not unique among reef coral species that are otherwise known for their massive growth form.

Apparently, the morphological plasticity and the presence of an epitheca enable $F$. gravida corals to survive as freeliving coral fragments. A free mode of life enables corals to colonize a wide variety of substrates, and consequently the whole corallum morphology may become affected by the environment as can be observed in Manicina (Johnson 1988; Hoeksema 1993; Sorauf and Harries 2010) and freeliving Fungiidae (Hoeksema and Moka 1989; Hoeksema 1993; Gittenberger and Hoeksema 2006). By not depending on a solid substratum for reproduction, the corals are completely adapted to a free mode of life. Since, this mode of life and reproduction in Favia has not been described before, it appears to be rare and may be confined just to some rock pools on Ascension Island.

Acknowledgments This study is dedicated to the memory of the naturalists J.C. (Koos) den Hartog (1942-2000) and J.H. Stock (1931-1997), who collected the corals (RMNH) from Ascension island that triggered the present study. I am grateful to Mr. E. Lazo Wasem (YPM), who sent the type specimens of F. gravida on loan, and to Dr. S.D. Cairns (USNM), who sent additional $F$. gravida material from Ascension I. on loan. I am indebted to two anonymous reviewers who provided very helpful and constructive comments on the ms.

Open Access This article is distributed under the terms of the Creative Commons Attribution Noncommercial License which permits any noncommercial use, distribution, and reproduction in any medium, provided the original author(s) and source are credited.

\section{References}

Abele LG, Felgenhauer BE (1985) Observations on the ecology and feeding behavior of the anchialine shrimp Procaris ascensionis. J Crust Biol 5:15-24

Amaral FD (1994) Morphological variation in the reef coral Montastrea cavernosa in Brazil. Coral Reefs 13:113-117 
Amaral FD, Ramos CAC (2007) Skeletal variability of the coral Favia gravida (Verrill, 1868) from Brazil. Biota Neotrop 7:245-251

Aronson R, Bruckner A, Moore J, Precht B, Weil E (2008) Favia fragum. In: IUCN 2010. IUCN Red List of Threatened Species. Version 2010.4. <www.iucnredlist.org>. Downloaded on 15 June 2011.

Barnes DJ (1972) The structure and formation of growth-ridges in scleractinian coral skeletons. Proc R Soc Lond B 182:331-350

Boschma H (1922) On budding and coalescence of buds in Fungia fungites and Fungia actiniformis. Proc K Ned Akad Wet 24:257-268

Boschma H (1923a) Experimental budding in Fungia fungites. Proc K Ned Akad Wet 26:88-96

Boschma H (1923b) Knospung und verwandte Erscheinungen bei Fungia fungites und Fungia actiniformis. Treubia 3:149-179

Boschma H (1923c) Über die Bildung der jungen Kolonien von Goniopora stokesi durch ungeschlechtliche Fortpflanzung. Zool Anz 57:284-286

Budd AF (1993) Variation within and among morphospecies of Montastraea. Cour Forschinst Senckenb 164:241-254

Budd AF, Stolarski J (2011) Corallite wall and septal microstructure in scleractinian reef corals: comparison of molecular clades within the family Faviidae. J Morphol 272:66-88

Cairns SD (1988) Asexual reproduction in solitary Scleractinia. Proc 6th Int Coral Reef Symp 2:641-646

Cairns SD (1989) A revision of the ahermatypic Scleractinia of the Philippine Islands and adjacent waters, Part 1: Fungiacyathidae, Micrabaciidae, Turbinoliinae, Guyniidae, and Flabellidae. Smithson Contrib Zool 486:1-136

Cairns SD, Zibrowius H (1997) Cnidaria Anthozoa: Azooxanthellate Scleractinia from the Philippine and Indonesian regions. Mem Mus Natn Hist Nat 172:27-243

Capel KCC, Segal B, Bertuol P, Lindner A (2011) Corallith beds at the edge of the tropical South Atlantic. Coral Reefs. doi:10.1007/ s00338-011-0818-3

Chace FA, Manning RB (1972) Two new caridean shrimps, one representing a new family, from marine pools on Ascension Island (Crustacea: Decapoda: Natantia). Smithson Contrib Zool 131:118

Chen KS, Hsieh HJ, Keshavmurthy S, Leung JKL, Lien IT, Nakano Y, Plathong S, Huang H, Chen CA (2011) Latitudinal gradient of morphological variations in Zebra Coral Oulastrea crispata (Scleractinia: Faviidae) in the West Pacific. Zool Stud 50:43-52

Correia MD (2011) Scleractinian corals (Cnidaria: Anthozoa) from reef ecosystems on the Alagoas coast, Brazil. J Mar Biol Assoc UK 91:659-668

Foster AB (1979) Phenotypic plasticity in the reef corals Montastraea annularis (Ellis \& Solander) and Siderastrea siderea (Ellis \& Solander). J Exp Mar Biol Ecol 39:25-54

Foster AB (1980) Environmental variation in skeletal morphology within the Caribbean reef corals Montastraea annularis and Siderastrea siderea. Bull Mar Sci 30:678-709

Fukami H, Budd AF, Levitan DR, Jara J, Kersanach R, Knowlton N (2004) Geographic differences in species boundaries among members of the Montastraea annularis complex based on molecular and morphological markers. Evolution 58:324-337

Gasparini JL, Floeter SR (2001) The shore fishes of Trindade Island, western South Atlantic. J Nat Hist 35:1639-1656

Gittenberger A, Hoeksema BW (2006) Phenotypic plasticity revealed by molecular studies on reef corals of Fungia (Cycloseris) spp. (Scleractinia: Fungiidae) near river outlets. Contrib Zool 75:195201

Gittenberger A, Reijnen BT, Hoeksema BW (2011) A molecularly based phylogeny reconstruction of mushroom corals (Scleractinia: Fungiidae) with taxonomic consequences and evolutionary implications for life history traits. Contrib Zool 80:107-132
Harries PJ, Sorauf JE (2010) Epi- and endobionts on and in free-living colonies of Manicina areolata (Cnidaria, Scleractinia): a comparison of two Pleistocene communities from southern Florida. Palaios 25:400-414

Hoeksema BW (1989) Taxonomy, phylogeny and biogeography of mushroom corals (Scleractinia: Fungiidae). Zool Verh 254:1-295

Hoeksema BW (1991) Evolution of body size in mushroom corals (Scleractinia: Fungiidae) and its ecomorphological consequences. Neth J Zool 41:122-139

Hoeksema BW (1993) Phenotypic corallum variability in Recent mobile reef corals. Cour Forschinst Senckenb 164:263-272

Hoeksema BW (2004) Impact of budding on free-living corals at East Kalimantan, Indonesia. Coral Reefs 23:492

Hoeksema BW, Gittenberger A (2010) High densities of mushroom coral fragments at West Halmahera, Indonesia. Coral Reefs 29:691

Hoeksema BW, Moka W (1989) Species assemblages and ecomorph variation of mushroom corals (Scleractinia: Fungiidae) related to reef habitats in the Flores Sea. Neth J Sea Res 23:149-160

Hoeksema BW, Waheed Z (2011) Initial phase of autotomy in fragmenting Cycloseris corals at Semporna, eastern Sabah, Malaysia. Coral Reefs 30:1087

Hoeksema BW, Waheed Z (in press) Size-dependent dispersal by Goniopora stokesi corals at Semporna, eastern Sabah, Malaysia. Galaxea J Coral Reef Res

Hoeksema BW, Yeemin T (2011) Late detachment conceals serial budding by the free-living coral Fungia fungites in the Inner Gulf of Thailand. Coral Reefs 30:975

Hoeksema BW, Van der Land J, Van der Meij SET, Van Ofwegen LP, Reijnen BT, Van Soest RWM, De Voogd NJ (2011) Unforeseen importance of historical collections as baselines to determine biotic change of coral reefs: the Saba Bank case. Mar Ecol 32:135-141

Hoeksema BW, Roos PJ, Cadée GC (in press) Trans-Atlantic rafting by the brooding reef coral Favia fragum on man-made flotsam. Mar Ecol Prog Ser. doi:10.3354/meps09460

Huang D, Meier R, Todd PA, Chou LM (2009) More evidence for pervasive paraphyly in scleractinian corals: systematic study of Southeast Asian Faviidae (Cnidaria; Scleractinia) based on molecular and morphological data. Mol Phylogenet Evol 50:102-116

Jackson JBC (1986) Modes of dispersal of clonal benthic invertebrates: consequences for species' distributions and genetic structure of local populations. Bull Mar Sci 39:588-606

Johnson KG (1988) Size, meander pattern, and behavior in the Caribbean free-living meandroid coral Manicina areolata (Linnaeus). Proc 6th Int Coral Reef Symp 3:403-408

Laborel J (1969) Madréporaires et hydrocoralliaires récifaux des côtes brésiliennes. Systématique, écologie, répartition verticale et géographique. Ann Inst Oceanogr 47:171-229

Laborel J (1974) West African reef corals: a hypothesis on their origin. Proc 2nd Int Coral Reef Symp 1:425-442

Linneaus C (1758) Systema Naturae. Regnum Animale. Laurentii Salvii, Holmiae, Stockholm

Lyman T (1859) On a new species of coral (Astraea decactis). Proc Boston Soc Nat Hist 6:260-263

Manning RB, Chace FA (1990) Decapod and stomatopod Crustacea from Ascension Island, South Atlantic Ocean. Smithson Contrib Zool 503:1-91

Nunes F, Fukami H, Vollmer SV, Norris RD, Knowlton N (2008) Reevaluation of the systematics of the endemic corals of Brazil by molecular data. Coral Reefs 27:423-432

Nunes FLD, Norris RD, Knowlton N (2011) Long distance dispersal and connectivity in amphi-Atlantic corals at regional and basin scales. PLoS One 6:e22298

Ow YX, Todd PA (2010) Light-induced morphological plasticity in the scleractinian coral Goniastrea pectinata and its functional significance. Coral Reefs 29:797-808 
Plusquellec Y, Webb G, Hoeksema BW (1999) Automobility in Tabulata, Rugosa, and extant scleractinian analogues: stratigraphic and paleogeographic distribution of Paleozoic mobile corals. J Paleontol 73:985-1001

Price H, John DM (1980) Ascension Island, south Atlantic: a survey of inshore benthic macroorganisms, communities and interactions. Aquat Bot 9:251-278

Ridley SO (1881) Report on a collection made by Mr. T. Conry in Ascension Island (Madreporaria). Ann Mag Nat Hist (Ser 5) $8: 438-440$

Roniewicz E, Stolarski J (1999) Evolutionary trends in the epithecate scleractinian corals. Acta Palaeontol Pol 44:131-166

Rosen BR, Taylor JD (1969) Reef coral from Aldabra: new mode of reproduction. Science 166:119-121

Sorauf JE, Harries PJ (2010) Morphologic variation in Manicina areolata (Cnidaria, Scleractinia) from the Pleistocene of South Florida. J Paleontol 84:505-517

Todd PA, Sanderson PG, Chou LM (2001) Morphological variation in the polyps of the scleractinian coral Favia speciosa (Dana) around Singapore. Hydrobiologia 444:227-235

Todd PA, Ladle RJ, Lewin-Koh NJI, Chou LM (2004) Genotype x environment interactions in transplanted clones of the massive corals Favia speciosa and Diploastrea heliopora. Mar Ecol Prog Ser 271:167-182

Van Veghel MLJ, Bak RPM (1993) Intraspecific variation of a dominant Caribbean reef building coral, Montastrea annularis: genetic, behavioral and morphometric aspects. Mar Ecol Prog Ser 92:255-265

Verrill AE (1901a) Variation and nomenclature of Bermudian, West Indian and Brazilian reef corals, with notes on various IndoPacific corals. Trans Conn Acad Arts Sci 11:63-168

Verrill AE (1901b) Comparison of the Bermudian, West Indian and Brazilian coral faunae. Trans Conn Acad Arts Sci 11:169-206

Wells JW (1966) Evolutionary development in the scleractinian family Fungiidae. Symp Zool Soc Lond 16:223-246

Werner TB (1996) Recent zooxanthellate corals (Order: Scleractinia) from Ascension and St. Helena Islands, South Atlantic, with a summary of their geographic distribution in the Atlantic Ocean. MS Thesis, University of Maryland, College Park (MD)

Wijsman-Best M (1974) Habitat-induced modification of reef corals (Faviidae) and its consequences for taxonomy. Proc 2nd Int Coral Reef Symp 2:217-228

Zibrowius H (1985) Asexual reproduction by bud-shedding in shallowwater Balanophyllia of the tropical Indo-Pacific. Proc 5th Int Coral Reef Congr 5:233-238 